\section{Cold Hardiness of Dormant Buds of Grape Cultivars: Comparison of Thermal Analysis and Field Survival}

\author{
Tony K. Wolf and M. Kay Cook \\ Winchester Agricultural Research and Extension Center, Virginia Polytechnic \\ Institute and State University, 595 Laurel Grove Road, Winchester, VA 22602
}

Additional index words. differential thermal analysis, grapevine, Vitis spp.

\begin{abstract}
Thermal analysis (TA) was used to evaluate dormant bud cold hardiness of nine Vitis cultivars weekly during the 1993-94 dormant period. TA hardiness estimates were expressed as either mean low-temperature exotherm temperature (MLTE) or temperatures lethal to $10 \%\left(\mathrm{LT}_{10}\right), 50 \%\left(\mathrm{LT}_{50}\right)$, or $\mathbf{9 0 \%}\left(\mathrm{LT}_{90}\right)$ of dormant bud sample. A destructive freeze on $19 \mathrm{Jan} .1994$ presented an opportunity to compare dormant bud field survival with laboratory estimates of bud hardiness that had been derived from TA. Vineyard air temperatures of $-24 \mathrm{C}$ caused primary bud kill that ranged from a mean of $15 \%$ with 'Concord' to $100 \%$ with 'Viognier'. With the exception of 'Viognier' and one of two 'Cabernet Sauvignon' clones, field mortality levels were accurately bracketed by TA estimates of $\mathrm{LT}_{10}$, MLTE, and $\mathrm{LT}_{90}$ values, which had been obtained in the week preceding the freeze. 'Viognier' bud hardiness was overestimated by $\approx 1.5 \mathrm{C}$, and the hardiness of 'Cabernet Sauvignon clone UCD\#6' was underestimated by <1C. The discrepancy with 'Viognier' may have been related to prior destruction of primary buds by bud necrosis and the misinterpretation of secondary bud exotherms as due to primary buds.
\end{abstract}

Thermal analysis (TA), including differential thermal analysis (DTA), is commonly used to measure cold hardiness of tissues and organs that avoid freezing by supercooling, such as floral buds of cherry (Prunus cerasus L.) (Callan, 1990) and peach [Prunus persica (L.) Batsch] (Durner and Gianfagna, 1991; Quamme, 1978) and the mixed buds of grape (Andrews et al., 1984; Quamme, 1986; Wolf and Pool, 1987). In practice, TA uses sensitive thermocouples or thermoelectric (TE) modules to detect the latent heat of fusion released when supercooled tissues freeze. Grape bud TA was originally explored by Pierquet et al. (1977) and Pierquet and Stushnoff (1980), who established a relationship between bud exothermic events and specific primordia destruction. Grape bud TA was modified by Andrews et al. (1984) to take advantage of the greater sensitivity and sample size afforded by TE modules. Refinements subsequently were made to freezing protocol (Quamme, 1986; Wolf and Pool, 1987). The advent of low-cost data-acquisition hardware (Wample et al., 1990; Wolf and Pool, 1986) has facilitated the

Received for publication 18 May 1994. Accepted for publication 20 Aug. 1994. Financial support for this research provided by the Virginia Winegrowers Advisory Board and the North Carolina Grape Council is gratefully acknowledged. Use of product names by Virginia Tech does not imply approval or recommendation of the product to the exclusion of others that also might be suitable. The cost of publishing this paper was defrayed in part by the payment of page charges. Under postal regulations, this paper therefore must be hereby marked advertisement solely to indicate this fact. application of grape bud TA to studies of genotypic differences (Pool et al., 1990) and response to the environment (Pool et al., 1992; Wolf and Cook, 1992) and cultural practices (Hamman et al., 1990; Wample et al., 1993).

The conviction that laboratory hardiness tests faithfully represent actual field hardiness is central to studies that seek to predict plant survival or damage in response to field conditions. Using TA as a measure of grape bud hardiness was examined in early TA research and found valid (Andrews et al., 1984; Quamme, 1986; Wolf and Pool, 1987). Typically, comparisons were made of TA and other laboratory techniques, such as browning of specific tissues following sample exposure to a range of test temperatures. Differences in hardiness estimates measured by these techniques were $\approx 1$ to $3 \mathrm{C}$. The ability of TA and DTA to accurately estimate bud cold hardiness can be affected by bud excision, the cooling rate, and other protocol; the technique also may be inappropriate for some systems (Flinn and Ashworth, 1994). Cooling rates of $\leq 10 \mathrm{C} / \mathrm{h}$ did not affect the low-temperature exotherm (LTE) temperature of grape bud TA (Quamme, 1986; Wolf and Pool, 1987), but LTE temperatures can be increased if buds are (Quamme, 1986; Wolf and Pool, 1987). Based on work with peaches (Ashworth and Davis, 1987), the attached nodal tissue may serve as an anatomical barrier to ice nucleation of the bud primordia.

Despite more than 10 years of use, there have been few opportunities to closely compare TA hardiness estimates with actual field survival following cold stress episodes. This report resulted from the occurrence of a damexcised without attached nodal tissue aging low-temperature episode on 19 Jan. 1994 that coincided with weekly TA estimates of grape bud cold hardiness. The data provided assurance that TA can accurately represent field hardiness, but some caution must be used interpreting exothermic events from samples of vines that have a significant proportion of previously destroyed primary buds.

\section{Materials and Methods}

Plant material. In this study, vines were grown at Virginia Tech's Winchester Agricultural Expt. Station, Winchester. Dormant bud cold hardiness of nine cultivars was evaluated weekly using TA from 29 Sept. 1993. Vitis vinifera L. cultivars were 'Cabernet Sauvignon clone UCD \#6', 'Cabernet Sauvignon clone UCD \#8', 'Fer Servadau', 'Petit Verdot', 'Riesling', and 'Viognier'. All vinifera cultivars were grafted to rootstock C-3309. Other cultivars were 'Concord' (V. labrusca L), 'Seyval' (Vitis hybrid), and 'Norton' (V. aestivalis Michx.). All cultivars, except 'Concord', 'Seyval', and 'Riesling', were part of an evaluation study established in 1989 of 22 cultivars. Each cultivar was planted in threevine plots, replicated five times, in a completely randomized design. 'Concord', 'Seyval', and 'Riesling' were planted in nonreplicated, independent rows in 1990 ('Seyval') and 1991 ('Concord' and 'Riesling'). All vines were spaced $2.1 \mathrm{~m}$ apart in north-south-oriented rows that were $3.7 \mathrm{~m}$ wide. Except for 'Concord' and 'Riesling', all vines were trained to bilateral cordons $(1.1 \mathrm{~m}$ above ground), spur-pruned, and shoots positioned vertically. 'Concord' and 'Riesling' were trained to Geneva Double Curtain and shoots positioned downwards. Shoot density ranged from 15 to 20 per meter of canopy, except with 'Seyval', which had a density of 12 to 15 shoots/meter. Two recording thermographs, with a verification thermometer, were located in the vineyard, each $1.5 \mathrm{~m}$ above ground in National Weather Service-approved instrument shelters. Thermograph calibration was checked on 19 Jan. 1994 at $-23 \mathrm{C}$ and $-26 \mathrm{C}$ in a freezer (model T20-S with Watlow 942 programmer; Tenney Environmental, Philadelphia) that held a constant temperature with $<1 \mathrm{C}$ variation.

Dormant bud TA. Weekly TA measures of dormant bud cold hardiness were made starting 29 Sept. 1993 and continuing through late Jan. 1994. For each cultivar, at least two representative canes were collected from different vines at each test date. Buds at node positions three to 15 were used for TA; they were excised in the laboratory and mounted on TE modules (MELCOR, Trenton, N.J.) with a strip of water-moistened filter paper to promote ice nucleation of moisture at the bud-TE module interface (Wolf and Pool, 1987). Buds were excised so that 0.5 to $1.0 \mathrm{~mm}$ of subtending nodal tissue remained attached to the bud. For each hardiness test, four or five buds were mounted on each of four or five TE modules, for a total of 20 buds per cultivar. Loaded modules were cooled from 0 to $-35 \mathrm{C}$, at $4 \mathrm{C} / \mathrm{h}$ in the previously described freezer. TE volt- 
age and separate thermocouple temperature data were recorded every $20 \mathrm{sec}$ with the dataacquisition hardware (Wolf and Pool, 1986). Data were subsequently plotted to determine the LTE temperature. The median primary bud LTE temperatures for each of the four or five TE modules were averaged to derive a single mean LTE (MLTE) value for each cultivar. In addition to MLTE temperatures, lethal temperature values were obtained for primary buds by ranking all primary bud LTEs for a given cultivar and determining the temperature lethal to $10 \%, 50 \%$, and $90 \%\left(\mathrm{LT}_{10}\right.$, $\mathrm{LT}_{50}$, and $\mathrm{LT}_{90}$, respectively) of the sample for each test date. The yield of LTEs judged to originate from primary buds was 0.9 to 1.0 . LTE "yield" represents the ratio of exotherms to the number of buds examined. Each compound grape bud should produce one primary bud exotherm; however, the actual exotherms : number of buds ratio in a sample usually averages less than one. Reductions in LTE yield can result from prior bud destruction, failure to register exotherms due to extended signal recording frequency, simultaneous bud freezing that superimposes two or more exotherms, and perhaps other reasons.

Assessment of bud kill from field exposure. Primary bud mortality was evaluated following the $19 \mathrm{Jan}$. freeze by collecting one representative cane per vine on 21 Jan. $(\approx 15$ canes per cultivar). The canes were held at $22 \mathrm{C}$ for 48 to $72 \mathrm{~h}$, after which buds at nodes three through 15 were sectioned with a razor and examined visually. The primary bud was judged dead if brown and alive if green. Previous to this exercise, a similar survey had been conducted 18 to 21 Nov. 1993 to determine the primary bud necrosis level (Morrison and Iodi, 1990) among all cultivars. The bud necrosis survey used three canes per vine, whereby buds at nodes three through 15 were sectioned with a razor and evaluated in a manner similar to that described for assessing freeze injury.

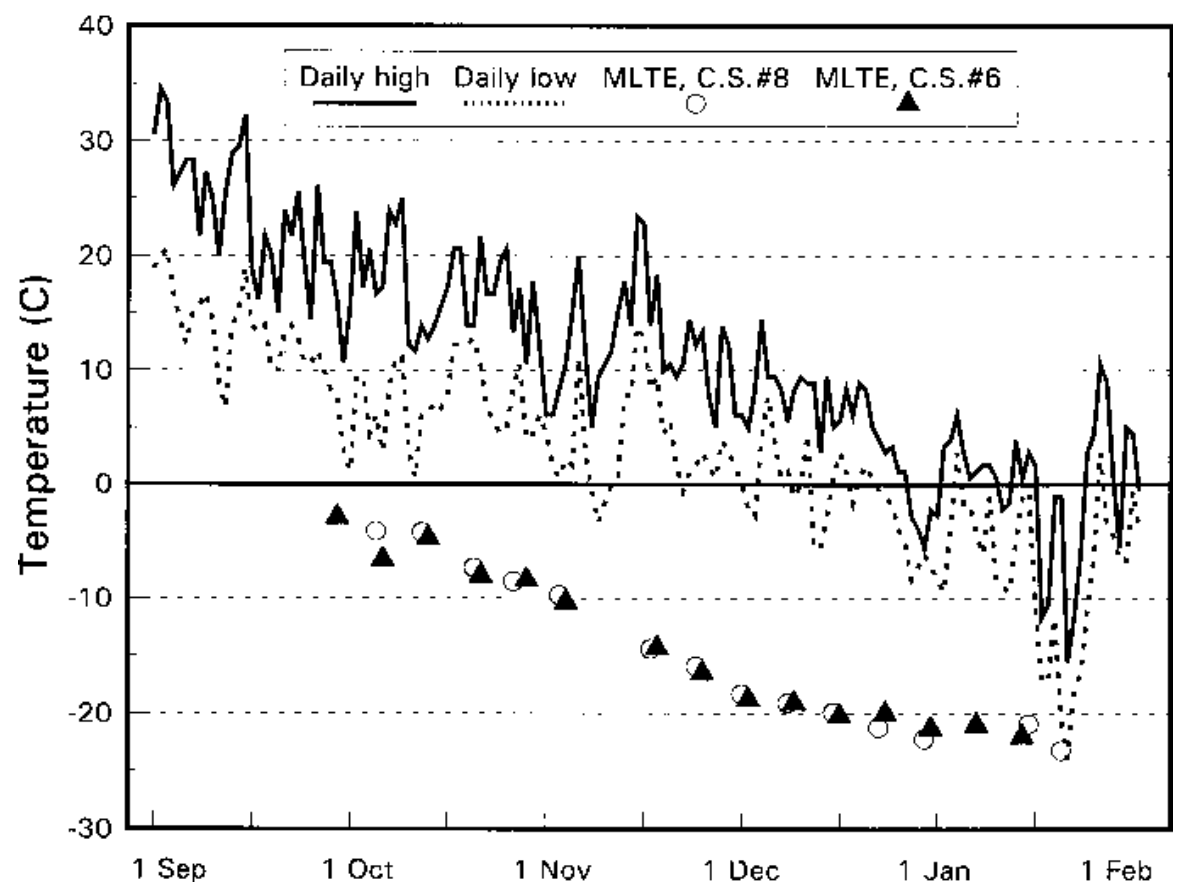

Fig. 1. Daily high and low air temperature at vineyard and mean low-temperature exotherm (MLTE) temperatures for 'Cabernet Sauvignon clone UCD\#8' and 'Cabernet Sauvignon clone UCD\#6' from 1 Sept. 1993 through 1 Feb. 1994.

\section{Results and Discussion}

Vineyard daily high and low temperatures from 1 Sept. 1993 through 1 Feb. 1994 are shown in Fig. 1. The first killing frost occurred 11 Nov., and temperatures throughout November and December were considered conducive to good cold hardiness acquisition. MLTE temperatures for the two 'Cabernet Sauvignon' clones decreased linearly through mid-December and attained levels by 1 Jan. that were lower than any previously recorded for this cultivar in Virginia (Wolf and Cook, 1992); acclimation conditions were excellent, at least for 'Cabernet Sauvignon' (Fig. 1). MLTE patterns for the other cultivars were similar in slope and stability to patterns shown for 'Cabernet Sauvignon'.

The period from 15 to 20 Jan. 1994 was characterized by unusually low temperatures. Both vineyard thermographs recorded a low of $-24 \mathrm{C}$ from 0600 to $0800 \mathrm{HR}$ on the morning of $19 \mathrm{Jan}$. Cooling rate in the vineyard was $0.7 \mathrm{C} /$ $\mathrm{h}$ from 1800 to $2400 \mathrm{HR}$ on $18 \mathrm{Jan}$. and $0.6 \mathrm{C} / \mathrm{h}$ from 0000 to $0800 \mathrm{HR}$ on $19 \mathrm{Jan}$. Records from the National Weather Service station at Dulles Airport, Chantilly, Va. (75 km away) indicated that sustained winds from 0000 to 0600 $\mathrm{HR}$ on $19 \mathrm{Jan}$. were no less than $3.6 \mathrm{~m} \cdot \mathrm{s}^{-1}$ and averaged $4.5 \mathrm{~m} \cdot \mathrm{s}^{-1}$. Given the wind, the vineyard's small size ( $\approx 1.0$ ha), and the uniform temperatures recorded in the vineyard, it is reasonable to presume that all plots experienced essentially the same temperature.

For seven of the nine cultivars evaluated during Winter 1993-94, TA provided a close approximation of actual bud hardiness as evaluated by bud kill following 19 Jan. (Table 1). MLTE temperatures and $\mathrm{LT}_{50}$ values (not shown) differed by no more than $0.7 \mathrm{C}$. Either estimate of hardiness could be used; however, MLTE temperature has more general use in TA studies and was the estimate of choice in Table 1 . Thermal analysis overestimated cold hardiness of 'Viognier' buds by $\geq 1.5 \mathrm{C}$. The Nov. 1993 survey indicated that 'Viognier' suffered $32 \%$ primary bud necrosis (Table 2 ). Causes of grape bud necrosis are unknown, but the condition observed in Virginia appeared similar to that described for table grapes in California (Morrison and Iodi, 1990) and Chile (Pérez and Kliewer, 1990). Bud necrosis also was observed among other cultivars but at

Table 1. Comparison of dormant bud cold hardiness measured by thermal analysis and field mortality sustained by nine Vitis cultivars before and as a result of exposure to $-24 \mathrm{C}$ on 19 Jan. 1994.

\begin{tabular}{|c|c|c|c|c|c|c|c|c|c|}
\hline \multirow{2}{*}{$\begin{array}{l}\text { Hardiness } \\
\text { test date }\end{array}$} & \multicolumn{3}{|c|}{ Cabernet Sauvignon $\# 8^{z}$} & \multicolumn{3}{|c|}{ Concord } & \multicolumn{3}{|c|}{ Riesling } \\
\hline & $\overline{\mathrm{LT}_{10}}$ & MLTE & $\overline{\mathrm{LT}_{90}}$ & $\overline{\mathrm{LT}_{10}}$ & MLTE & $\overline{\mathrm{LT}_{90}}$ & $\mathrm{LT}_{10}$ & MLTE & $\mathrm{LT}_{90}$ \\
\hline 13 Jan. & -18.3 & -21.1 & -22.8 & -20.0 & -25.6 & -27.2 & -21.1 & -23.3 & -25.0 \\
\hline 18 Jan. & -20.5 & -23.3 & -24.4 & -20.5 & -26.1 & -30.6 & -20.0 & -25.0 & -26.1 \\
\hline \multirow[t]{2}{*}{ Dead primary buds $(\%)^{\mathrm{y}}$} & \multirow{2}{*}{\multicolumn{3}{|c|}{$\begin{array}{c}90 \\
\text { Norton }\end{array}$}} & \multirow{2}{*}{\multicolumn{3}{|c|}{$\begin{array}{c}15 \\
\text { Viognier }\end{array}$}} & \multirow{2}{*}{\multicolumn{3}{|c|}{$\begin{array}{c}37 \\
\text { Seyval }\end{array}$}} \\
\hline & & & & & & & & & \\
\hline 10 Jan. & -25.6 & -28.3 & -29.4 & -21.1 & -23.9 & -25.0 & -23.3 & -25.0 & -27.8 \\
\hline 17 Jan. & -23.3 & -28.9 & -30.6 & -22.9 & -24.2 & -25.5 & -17.8 & -25.6 & -28.3 \\
\hline \multirow[t]{2}{*}{ Dead primary buds $(\%)^{\mathrm{y}}$} & \multirow{2}{*}{\multicolumn{3}{|c|}{$\begin{array}{c}22 \\
\text { Cabernet Sauvignon \#6 }\end{array}$}} & & 100 & & & 32 & \\
\hline & & & & \multicolumn{3}{|c|}{ Petit Verdot } & \multicolumn{3}{|c|}{ Fer Servadau } \\
\hline 5 Jan. & -19.4 & -21.1 & -22.2 & -18.3 & -22.2 & -23.9 & -18.9 & -20.5 & -22.8 \\
\hline 12 Jan. & -20.5 & -22.2 & -23.3 & -17.8 & -22.2 & -23.9 & -18.3 & -21.1 & -23.9 \\
\hline Dead primary buds $(\%)^{\mathrm{y}}$ & & 76 & & & 95 & & & 99 & \\
\hline
\end{tabular}

${ }^{2} \mathrm{LT}_{10}=$ temperature lethal to $10 \%$ of a bud sample; MLTE $=$ mean low-temperature exotherm temperature; $\mathrm{LT}_{90}=$ temperature lethal to $90 \%$ of a bud sample. y Determined on 21 Jan. 
Table 2. Cultivar differences in primary bud destruction resulting from bud necrosis (assessed Nov. 1993) and field exposure to $-24 \mathrm{C}$ on 19 Jan. 1994. Canes from nonreplicated cultivars were randomly collected from at least five vines. Percentage data were square-root-transformed before analysis of variance but are shown as nontransformed values.

\begin{tabular}{|c|c|c|c|c|}
\hline \multirow[b]{2}{*}{ Cultivar } & \multicolumn{2}{|c|}{$\begin{array}{c}\text { Bud } \\
\text { necrosis }\end{array}$} & \multicolumn{2}{|c|}{$\begin{array}{l}\text { Cold- } \\
\text { injured }\end{array}$} \\
\hline & $\mathrm{n}^{\mathrm{z}}$ & $\% \%^{y}$ & $n^{2}$ & $\%{ }^{y}$ \\
\hline Viognier & 18 & $31.5 \mathrm{~A}$ & 10 & $100 \mathrm{~A}$ \\
\hline Fer Servadau & 22 & $5.3 \mathrm{~B}$ & 13 & $99 \mathrm{~A}$ \\
\hline Petit Verdot & 12 & $0.0 \mathrm{~B}$ & 8 & $95 \mathrm{AB}$ \\
\hline \multicolumn{5}{|c|}{ Cabernet Sauvignon } \\
\hline Clone \#8 & 30 & $5.7 \mathrm{~B}$ & 15 & $90 \mathrm{AF}$ \\
\hline \multicolumn{5}{|c|}{ Cabernet Sauvignon } \\
\hline Clone \#6 & 30 & $3.2 \mathrm{~B}$ & 15 & $76 \mathrm{~B}$ \\
\hline Riesling & 10 & $0.6^{\mathrm{x}}$ & 10 & $37^{x}$ \\
\hline Seyval & 20 & $1.3^{\mathrm{x}}$ & 12 & $32^{x}$ \\
\hline Norton & 12 & $4.8 \mathrm{~B}$ & 13 & $22 \mathrm{C}$ \\
\hline Concord & --- & $---x$ & 10 & $15^{x}$ \\
\hline
\end{tabular}

${ }^{\mathrm{z}} \mathrm{n}=$ number of canes examined

'Mean separation within rows by Duncan's multiple range test at $P \leq 0.05$; nonreplicated vines were not included in mean separation.

${ }^{\mathrm{x}}$ Not replicated

$<6 \%$. Interpretation of grape bud LTEs is complicated by the presence of secondary buds, usually two, in the compound structure (Pratt, 1974). Primary bud exotherms are judged on the basis of their greater size and higher temperature of occurrence than those of secondary buds; however, some subjectivity is inherent with interpretation. We suspect that the hardiness discrepancy with 'Viognier' was produced by including some secondary bud LTEs in the data interpretation, even though 'Viognier' LTE yield was expected to be lower $(\approx 0.7)$ due to $32 \%$ primary bud necrosis. Although the cold hardiness of 'Cabernet Sauvignon clone UCD \#6' was slightly underestimated, the discrepancy was reasonable, particularly because it had been $>6$ days since the last MLTE determination. No attempt was made to estimate the cold hardiness of secondary buds or to methodically tally secondary bud mortality in the field, although this exer- cise would have been possible. Due to the significant cold injury on 19 Jan. (Table 2), further hardiness tests during Winter 1993-94 were suspended.

We demonstrated that TA can accurately estimate dormant bud cold hardiness of the Vitis species and an interspecific hybrid that represent a wide range of inherent cold hardiness. In addition to relative differences in cold hardiness between population samples, TA can be confidently used to estimate the absolute cold hardiness of buds. Some caution must be used in estimating the cold hardiness of a population that has a significant incidence of nonfreeze injury, and some judgment is required to distinguish the LTEs of primary and secondary buds if this is of interest to the researcher.

\section{Literature Cited}

Andrews, P.K., C.R. Sandidge, III, and T.K. Toyama 1984. Deep super-cooling of dormant and deacclimating Vitis buds. Amer. J.Enol. Viticult. 35:175-177.

Ashworth, E.N. and G.A. Davis. 1987. Influence of ice nucleation temperature on the freezing of peach flower buds. HortScience 22:923-925.

Callan, N.W. 1990. Dormancy effects on supercooling in deacclimated 'Meteor' tart cherry flower buds. J. Amer. Soc. Hort. Sci. 115:982-986.

Durner, E.F. and T.J. Gianfagna. 1991. Ethephon prolongs dormancy and enhances supercooling in peach flower buds. J. Amer. Soc. Hort. Sci. 116:500-506

Flinn, C.L. and E.N. Ashworth. 1994. Blueberry flower-bud hardiness is not estimated by differential thermal analysis. J. Amer. Soc. Hort. Sci. 119:295-298

Hamman, R.A., Jr., A.R. Renquist, and H.G. Hughes. 1990. Pruning effects on cold hardiness and water content during deacclimation of Merlot bud and cane tissues. Amer J. Enol. Viticult. 41:251-260.

Morrison, J.C. and M. Iodi. 1990. The development of primary bud necrosis in Thompson Seedless and Flame Seedless grapevines. Vitis 29:133144.

Pérez, J. and W.M. Kliewer. 1990. Effect of shading on bud necrosis and bud fruitfulness of Thompson Seedless grapevines.
Amer. J. Enol. Viticult. 41:168-175.

Pierquet, P. and C. Stushnoff. 1980. Relationship of low temperature exotherms to cold injury in Vitis riparia Michx. Amer. J. Enol. Viticult. 31:1-6.

Pierquet, P., C. Stushnoff, and M.J. Burke. 1977. Low temperature exotherms in stem and bud tissues of Vitis riparia Michx. J. Amer. Soc. Hort. Sci. 102:54-55.

Pool, R.M., B.I. Reisch, and M.J. Welser. 1990. Use of differential thermal analysis to quantify bud cold hardiness of grape selections and clones, $\mathrm{p}$. 318-329. In: Proc. 5th Intl. Symp. on Grape Breeding. Bundesforschungsanstalt für Rebenzüchtung, Geilweilerhof, Germany. (Vitis special issue).

Pool, R.M., T.K. Wolf, M.J. Welser, and M.C. Goffinet. 1992. Environmental factors affecting dormant bud cold acclimation of three Vitis cultivars, p. 611-616. Proc. IV Intl. Symp. Physiol. Vine, San Michele All'Adige, Italy, 10-15 May 1992.

Pratt, C. 1974. Vegetative anatomy of cultivated grapes-A review. Amer. J. Enol. Viticult. 25:131-150.

Quamme, H.A. 1978. Mechanism of supercooling in overwintering peach flower buds. J. Amer. Soc. Hort. Sci. 103:57-61.

Quamme, H.A. 1986. Use of thermal analysis to measure freezing resistance of grape buds. Can. J. Plant Sci. 66:945-952.

Wample, R.L., G. Reisenauer, A. Bary, and F Scheutze. 1990. Microcomputer-controlled freezing, data acquisition, and analysis system for cold hardiness evaluation. HortScience 25:973-976.

Wample, R.L., S.E. Spayd, R.G. Evans, and R.G. Stevens. 1993. Nitrogen fertilization of White Riesling grapes in Washington: Nitrogen seasonal effects on bud cold hardiness and carbohydrate reserves. Amer. J. Enol. Viticult. 44:159167.

Wolf, T.K. and M.K. Cook. 1992. Seasonal deacclimation patterns of three grape cultivars at constant, warm temperature. Amer. J. Enol. Viticult. 43:171-179.

Wolf, T.K. and R.M. Pool. 1986. Microcomputerbased differential thermal analysis of grapevine dormant buds. HortScience 21:1447-1448.

Wolf, T.K. and R.M. Pool. 1987. Factors affecting exotherm detection in the differential thermal analysis of grapevine dormant buds. J. Amer. Soc. Hort. Sci. 112:520-525. 